\title{
PENGARUH KONSENTRASI GIBERELIN (GA3) TERHADAP PERKECAMBAHAN BEBERAPA VARIETAS PADI SAWAH PADA CEKAMAN SALINITAS TINGGI
}

\section{THE EFFECT OF GIBERELIN (GA3) CONCENTRATION ON GERMINATION OF SEVERAL RICE FIELD VARIETIES IN HIGH SALINITY STRESSES}

\author{
Roni Assafaat Hadi ${ }^{* 1}$ \\ ${ }^{1}$ Jurusan Agroteknologi, Fakultas Pertanian, Universitas Winaya Mukti \\ Jalan Raya Tanjungsari Km. 29 Bandung - Sumedang 45362, Jawa Barat \\ *Korespondensi: roni.assafaat.hadi@gmail.com
}

\begin{abstract}
ABSTRAK
Penelitian ini bertujuan untuk : (1) mempelajari pengaruh interaksi antara konsentrasi giberelin $\left(\mathrm{GA}_{3}\right)$ dengan beberapa varietas padi sawah pada kondisi cekaman salinitas tinggi terhadap perkecambahan, dan (2) konsentrasi giberelin $\left(\mathrm{GA}_{3}\right)$ dan varietas padi sawah yang memberikan pengaruh terbaik terhadap perkecambahan,padi sawah. Penelitian dilaksanakan di Laboratorium dan Screen House Fakultas Pertanian Universitas Winaya Mukti Tanjungsari - Kabupaten Sumedang dengan ketinggian tempat $850 \mathrm{~m}$ dpl. Adapun waktu penelitian dilaksanakan pada bulan Desember 2014 sampai dengan bulan April 2015. Penelitian menggunakan metode Rancangan Acak Kelompok (RAK) pola faktorial, yang terdiri atas dua faktor yaitu konsentrasi giberelin $\left(\mathrm{GA}_{3}\right)$ dan beberapa verietas padi sawah pada cekaman salinitas tinggi. Faktor pertama adalah konsentrasi giberelin $\left(\mathrm{GA}_{3}\right)(\mathrm{G})$, terdiri atas empat taraf : $\mathrm{g} 0=$ perendaman benih selama 24 jam dalam giberelin $0 \mathrm{mg} . \mathrm{L}^{-1}$, $\mathrm{g} 1$ = perendaman benih selama 24 jam dalam giberelin $20 \mathrm{mg} \cdot \mathrm{L}^{-1}, \mathrm{~g} 2$ = perendaman benih selama 24 jam dalam giberelin $40 \mathrm{mg} . \mathrm{L}^{-1}, \mathrm{~g} 3=$ perendaman benih selama 24 jam dalam giberelin $60 \mathrm{mg} \mathrm{L}^{-1}$. Faktor kedua adalah varietas padi sawah (P), terdiri atas delapan taraf : $\mathrm{p} 1=$ Inpari $10, \mathrm{p} 2=$ Inpari 20, p3 = Inpari 25, p4 = Inpari 26, p5 = Inpari 27, p6 = Inpari 30, p7 = Inpara 4, dan p8 = Banyuasin. Hasil penelitian menunjukkan bahwa tterdapat pengaruh interaksi antara konsentrasi giberelin dan beberapa varietas padi sawah pada cekaman salinitas tinggi terhadap perkecambahan padi sawah dan terdapat konsentrasi giberelin $\left(\mathrm{GA}_{3}\right)$ dan varietas padi sawah yang menghasilkan perkecambahan, pertumbuhan dan hasil terbaik pada cekaman salinitas tinggi.
\end{abstract}

Kata kunci: Konsentrasi Giberelin (GA3), Varietas Padi Sawah dan Cekaman Salinitas Tinggi.

\begin{abstract}
This study examines the effect of gibberellin concentration (GA3) on germination, growth and yield components of rice varieties on flood-prone land. Based on these objectives, the nature of this research is verification carried out by an experimental approach in the screen house and in the field. The research was conducted at the screen house and in the field of production garden of the Faculty of Agriculture, University of Winaya Mukti Tanjungsari - Sumedang, with altitude $850 \mathrm{~m}$ above sea level. Experiments using factorial randomized block design (RBD) consisted of two factors, namely four levels of gibberellin concentration and five levels of West Java local rice varieties. Each treatment is repeated twice, the total number: $4 \times 5 \times 2=40$ plots. Based on the results of the research and discussion described earlier, it can be concluded that the germination of flood-prone rice fields, including: Gibberellin (g2) concentration of $10 \mathrm{mg}$. $\mathrm{L}^{-1}$ gives the best results on observations for each local Egyptian variety (v1). Rice varieties independently affect the number of 14 HST sprouts (days after planting), and seed vigor.
\end{abstract}

Keywords: Rice Germination, Rice Varieties, and Gibberelin Acid (GA3) 


\section{PENDAHULUAN}

Beras merupakan makanan pokok masyarakat di Indonesia. Kebutuhan akan beras bagi Indonesia dari tahun ke tahun akan semakin meningkat seiring dengan pertambahan jumlah penduduk. Estimasi laju pertumbuhan penduduk Indonesia pada rentang waktu 2005 - 2010 adalah 1,3\% dengan jumlah penduduk 233,48 juta jiwa dan tingkat konsumsi beras bruto $139,5 \mathrm{~kg}$ per kapita, maka kebutuhan beras mencapai 32,49 juta ton. Sedangkan pada 2025 - 2030 laju pertumbuhan penduduk diperkirakan mencapai 0,92\%. Dengan kata lain, apabila jumlah penduduk menjadi 286,02 juta jiwa dan tingkat konsumsi beras tetap 139,5 kg per kapita, maka kebutuhan beras menjadi 39,8 juta ton. Untuk mengantisipasi penambahan jumlah penduduk tersebut, maka Indonesia setidaknya harus menambah ketersediaan beras nasional hingga tujuh juta ton pada 2025 - 2030 (Direktorat Jenderal Prasarana dan Sarana Pertanian, 2013).

Keberadaan lahan sawah di Pantura (pantai utara Pulau Jawa) sangat strategis bagi kecukupan beras nasional. Luas lahan sawah di Indonesia mencapai 7,75 juta ha, sekitar 42,8\% (3,32 juta ha) diantaranya berada di Pulau Jawa yang tersebar terutama di daerah Pantura. Lahan sawah di daerah Pantura sangat penting mengingat daerah tersebut merupakan salah satu lumbung padi Nasional. Tetapi pada kenyataannya produksi padi di kawasan tersebut pun mengalami penurunan. Pelandaian produksi salah satunya disebabkan oleh kadar salinitas yang cukup tinggi di lahan sawah, sehingga mempengaruhi sifat-sifat tanah dan mengganggu pertumbuhan tanaman padi (Marwanto et al., 2009). Pada lahan-lahan pantai sering memunculkan tanah-tanah salin sebagai akumulasi garam akibat kekeringan pada musim kemarau (Sumarsono et al., 2006). Menurut Badan Penelitian dan Pengembangan Pertanian (2007), lahan salin yaitu lahan yang mendapat intrusi air laut sehingga mengandung garam dengan konsentrasi yang tinggi, terutama pada musim kemarau luasannya sekitar 2\%. Lahan salin di Indonesia akan semakin meningkat mengingat Indonesia merupakan negara kepulauan yang mempunyai garis pantai yang panjang dengan daerah produksi padi di Indonesia berada di pinggir pantai seperti di pulau Jawa, Sulawesi dan yang lainnya. Disamping itu banyaknya bencana alam seperti gempa bumi yang mengakibatkan tsunami dan abrasi air laut juga memperluas lahan salin di Indonesia. Masalah salinitas ini telah menjadi masalah nasional yang harus ditangani, terutama sekali untuk mempertahankan atau meningkatkan produksi padi di Indonesia.

Kadar salinitas tinggi yang mempengaruhi sifat-sifat tanah dan pertumbuhan tanaman padi disebut juga sebagai cekaman salinitas tinggi. Cekaman dapat didefinisikan sebagai perubahan lingkungan yang menyebabkan penurunan terhadap pertumbuhan, penurunan hasil, aklimatisasi fisiologi atau adaptasi spesies. Cekaman salinitas terjadi sebagai akibat deposit garam. Salinitas mengurangi pertumbuhan dan hasil tanaman pertanian penting dan pada kondisi terburuk dapat menyebabkan terjadinya gagal panen. 
Pengaruh utama salinitas adalah berkurangnya pertumbuhan daun yang langsung mengakibatkan berkurangnya fotosintesis tanaman. Pada kondisi salin, pertumbuhan dan perkembangan tanaman terhambat karena akumulasi berlebihan $\mathrm{Na}$ dan Cl dalam sitoplasma, menyebabkan perubahan metabolisme di dalam sel. Aktivitas enzim terhambat oleh garam. Kondisi tersebut juga mengakibatkan dehidrasi parsial sel dan hilangnya turgor sel karena berkurangnya potensial air di dalam sel. Berlebihnya $\mathrm{Na}$ dan $\mathrm{Cl}$ ekstraselular juga mempengaruhi asimilasi nitrogen karena berdampak menghambat penyerapan nitrat $\left(\mathrm{NO}_{3}\right)$ yang merupakan ion penting untuk pertumbuhan tanaman (Yuniati, 2004).

Berbagai upaya untuk mengatasi kondisi tersebut diatas perlu dilakukan, seperti pemberian zat pengatur tumbuh giberelin dan penapisan beberapa varietas padi sawah yang toleran terhadap salinitas. Sejak sekitar tahun 1955, giberelin telah diketahui dapat mendorong perkecambahan benih. Giberelin dapat mengganti fungsi dari kebutuhan akan cahaya dan temperatur dalam mendorong perkecambahan. Giberelin dipercaya sangat penting untuk mengontrol perkecambahan benih secara alami (Copeland, 1978). Giberelin adalah salah satu bentuk zat pengatur tumbuh yang secara alami terdapat dalam jaringan tanaman. Pada tanaman padi, giberelin berperan meningkatkan tinggi padi tipe kerdil. Hasil penelitian Yan et al., (2004), menunjukkan bahwa giberelin dapat memperbaiki perkecambahan dan kekokohan tanaman padi tipe kerdil, menghasilkan perkecambahan dalam waktu yang singkat. Ditambahkan efek giberelin ini terlihat lebih berpengaruh dalam kondisi stress. Seperti halnya kondisi stress akibat cekaman salinitas, sehingga pemberian giberelin pada tanaman padi semenjak dari benih diharapkan dapat diaplikasikan untuk mendapatkan hasil yang lebih baik.

Upaya peningkatan produksi padi dengan menggunakan varietas unggul bermutu sangat dianjurkan, terutama penggunaan varietas unggul yang toleran dan berproduksi baik pada lingkungan dimana tanaman tersebut ditanam. Tetapi jumlah varietas seperti yang disebut masih sangat terbatas, sehingga diperlukan pencarian lebih lanjut salah satunya dengan melakukan penapisan beberapa varietas agar didapat varietas terbaik untuk ditanam pada lingkungan yang diinginkan.

Setiap varietas pada tanaman padi memiliki ciri-ciri khusus yang membedakan antara satu dengan yang lainnya, seperti : tinggi tanaman, umur tanaman, bentuk bulir, ukuran bulir, jumlah malai, hasil gabah dan ciri-ciri khusus lainnya. Begitu juga dengan responnya terhadap faktor lingkungan dan faktor pemberian zat pengatur tumbuh, seperti pengaruh dari lingkungan tercekam salinitas dan pemberian zat pengatur tumbuh giberelin, dipastikan akan menghasilkan lebih banyak keragaman ke-khasan baik antar varietas maupun dalam satu varietas yang sama. 
Tabel 1. Varietas Unggul Padi Lahan Rawa Pasang Surut

\begin{tabular}{|c|c|c|c|c|}
\hline Varietas & $\begin{array}{l}\text { Umur } \\
\text { (hari) }\end{array}$ & $\begin{array}{l}\text { Tinggi } \\
\text { tanaman } \\
(\mathbf{c m})\end{array}$ & $\begin{array}{l}\text { Tekstur } \\
\text { nasi }\end{array}$ & Tahan/toleran \\
\hline Banyuasin & 120 & 105 & Pulen & $\begin{array}{l}\text { Wereng cokelat 3, blas, hawar daun bakteri } \\
\text { III, keracunan Fe dan keracunan } \mathrm{Al}\end{array}$ \\
\hline Batanghari & 125 & 110 & Pera & $\begin{array}{l}\text { Wereng cokelat } 1 \text { dan } 2 \text {, blas, hawar daun } \\
\text { bakteri III, dan keracunan Fe }\end{array}$ \\
\hline Dendang & 125 & 100 & Pulen & $\begin{array}{l}\text { Wereng cokelat } 1 \text { dan } 2 \text {, blas, bercak } \\
\text { cokelat, keracunan Fe dan keracunan } \mathrm{Al}\end{array}$ \\
\hline Indragiri & 117 & 105 & Sedang & $\begin{array}{l}\text { Wereng cokelat } 1 \text { dan } 2 \text {, blas, hawar daun } \\
\text { bakteri III, dan keracunan Fe dan } \\
\text { keracunan } \mathrm{Al}\end{array}$ \\
\hline Punggur & 117 & 100 & Sedang & $\begin{array}{l}\text { Wereng cokelat } 1 \text { dan } 2 \text {, blas, keracunan } \mathrm{Fe} \\
\text { dan keracunan } \mathrm{Al}\end{array}$ \\
\hline Martapura & 125 & 120 & Pera & Keracunan Fe, blas \\
\hline Margasari & 125 & 120 & Pera & Keracunan Fe, blas \\
\hline Siak Raya & 120 & 120 & Pera & $\begin{array}{l}\text { Hawar daun bakteri III dan IV, blas, } \\
\text { keracunan Fe dan keracunan } \mathrm{Al}\end{array}$ \\
\hline Air Tenggulang & 125 & 120 & Pera & $\begin{array}{l}\text { Wereng cokelat } 2 \text {, blas, hawar daun bakteri } \\
\text { III dan IV, bercak cokelat, keracunan Fe dan } \\
\text { keracunan } \mathrm{Al}\end{array}$ \\
\hline Lambur & 115 & 100 & Pulen & $\begin{array}{l}\text { Blas, keracunan } \mathrm{Fe} \text {, keracunan } \mathrm{Al} \text { dan } \\
\text { salinitas }\end{array}$ \\
\hline Mendawak & 115 & 100 & Pulen & $\begin{array}{l}\text { Blas, bercak cokelat, keracunan Fe dan } \\
\text { salinitas }\end{array}$ \\
\hline Sei Lalan & 125 & 100 & Pera & $\begin{array}{l}\text { Wereng cokelat } 2 \text { dan } 3 \text {, blas, bercak } \\
\text { cokelat dan salinitas }\end{array}$ \\
\hline IR 42 & 140 & 110 & Pera & $\begin{array}{l}\text { Wereng cokelat } 1 \text { dan } 2 \text {, hawar daun } \\
\text { bakteri, blas, kemasaman tanah }\end{array}$ \\
\hline
\end{tabular}

Sumber: Badan Penelitian dan Pengembangan Pertanian (2007).

Banyaknya petani yang menanam padi pada lahan yang berkadar garam tinggi, menunjukkan adanya seleksi alamiah sifat toleran terhadap salinitas (Moorman dan Breemen, 1978). Selanjutnya Castro dan Sabado (1977), menyebutkan bahwa varietas padi mempunyai perbedaan keragaman yang luas di dalam kepekaannya terhadap salinitas. Pengembangan padi di lahan salin masih mendapat kendala dengan terbatasnya jumlah varietas yang cocok untuk dikembangkan di daerah tersebut dan juga sedikitnya plasma nutfah sebagai donor gen sifat toleran lahan salin dalam upaya perbaikan varietas toleran salinitas, sehingga dengan demikian pemulia tanaman mempunyai peluang untuk memanfaatkannya dalam usaha perbaikan varietas. Menurut Badan Penelitian dan Pengembangan Pertanian (2007), padi varietas unggul untuk lahan salin dapat dilihat pada Tabel 1.

Berdasarkan Tabel 1 dapat diambil contoh beberapa varietas padi yang baik untuk ditanam di lahan salinitas tinggi sebagai kontrol bagi varietas padi sawah yang akan diujicobakan. Sulaiman (1980), menyatakan bahwa penggunaan larutan garam sebanyak 4000 mg.L ${ }^{-1} \mathrm{NaCl}$ pada media tanah merupakan indikator yang baik untuk menilai toleransi tanaman padi terhadap salinitas. Begitu juga dengan penelitian Suwarno dan Solahudin (1983), menyebutkan bahwa hasil 
studi fisiologi tanaman padi menunjukan bahwa larutan hara dengan $4000 \mathrm{mg} . \mathrm{L}^{-1} \mathrm{NaCl}$ cukup baik untuk pengujian toleransi terhadap salinitas. Kedua pernyataan di atas memberikan gambaran besaran toleransi tanaman padi terhadap salinitas dalam lingkungan ex-situ, dimana pengujian pada lingkungan yang tidak sebenarnya akan memberikan kemudahan baik dari segi materi maupun non materi, sebagai contoh penanaman pada pot, polybag ataupun ember yang telah di kondisikan sedemikian rupa menyerupai lingkungan aslinya.

Pengaruh salinitas tanah tergantung pada tingkatan pertumbuhan tanaman, biasanya pada tingkatan perkecambahan sangat peka terhadap salinitas. Seperti yang dimaksud oleh Pearson dan Ayres (1960) dalam Sriwidodo (1985), bahwasanya salinitas dapat merusak tanaman padi pada semua stadia pertumbuhan tanaman dimulai dari stadia perkecambahan, sehingga pengujian berikutnya dapat dilakukan terhadap tanaman padi pada fase benih atau perkecambahan benih. Dalam penelitiannya Sadjad (1993), mengemukakan bahwa pengujian vigor benih pada fase perkecambahan merupakan metode seleksi yang cepat dan efisien dalam menentukan tingkat toleransi suatu genotip, sehingga sangatlah tepat jika pengujian penapisan varietas padi yang toleran terhadap salinitas dilakukan semenjak umur perkecambahan.

Kondisi penanaman padi pada lingkungan dengan cekaman salinitas tinggi tentu akan mempengaruhi terhadap perkecambahan tanaman padi. Setiap varietas padi memiliki susunan genetik yang berbeda- beda, sehingga respons akibat akumulasi kandungan garam yang tinggi dan pengaruhnya terhadap pemberian zat pengatur tumbuh giberelin pun akan berbeda, sehingga peningkatan perkecambahan, pertumbuhan dan hasil tanaman padi akan terlihat akibat pengaruh pemberian zat pengatur tumbuh giberelin dengan konsentrasi yang tepat.

\section{BAHAN DAN METODE}

Penelitian ini mengkaji pengaruh interaksi antara konsentrasi giberelin dengan beberapa varietas padi sawah pada cekaman salinitas tinggi terhadap perkecambahan dan konsentrasi giberelin $\left(\mathrm{GA}_{3}\right)$ dan varietas padi sawah yang menghasilkan perkecambahan terbaik pada cekaman salinitas tinggi. Berdasarkan tujuan tersebut maka sifat dari penelitian ini adalah verifikatif dilakukan dengan pendekatan eksperimen di laboratorium.

Penelitian dilaksanakan di Laboratorium Teknologi Benih dan Screen House (SH) Fakultas Pertanian Universitas Winaya Mukti Tanjungsari - Sumedang, dengan ketinggian tempat $850 \mathrm{~m}$ dpl. Waktu penelitian dilaksanakan mulai dari bulan Desember 2014 sampai dengan bulan April 2015. Eksperimen menggunakan Rancangan Acak Kelompok (RAK) pola faktorial, yang terdiri dari dua faktor yaitu empat taraf konsentrasi giberelin dan delapan taraf varietas padi sawah. Tiap perlakuan diulang sebanyak dua kali, maka jumlah keseluruhan: $4 \times 8 \times 2=64$ plot.

Respon perkecambahan tanaman dalam rangka menguji hipotesis, dilakukan analisis varians (uji F) dengan model linier 
Rancangan Acak Kelompok (RAK) pola faktorial yang dikemukakan oleh Warsa dan Cucu (1982), sebagai berikut:

$\mathrm{Y}_{\mathrm{ijk}}=\mu+\mathrm{r}_{\mathrm{i}}+\mathrm{p}_{\mathrm{j}}+\mathrm{v}_{\mathrm{k}}+(\mathrm{pv})_{\mathrm{jk}}+\varepsilon_{\mathrm{ijk}}$

\section{HASIL DAN PEMBAHASAN}

\section{Respons Penunjang}

Pengamatan penunjang dalam percobaan ini meliputi suhu selama percobaan di screen house dan di lapangan, kelembaban udara di screen house dan di lapangan, serangan hama dan penyakit pada saat perkecambahan dan gulma yang tumbuh dominan baik pada saat perkecambahan tanaman. Keadaan suhu udara rata-rata selama percobaan suhu udara rata-rata di dalam screen house adalah $24{ }^{\circ} \mathrm{C}$ dan kelembaban udara relatifnya adalah rata-rata $81,2 \%$. Sedangkan suhu udara rata-rata di lapangan adalah $23{ }^{\circ} \mathrm{C}$ dan kelembaban udara relatifnya adalah rata-rata $82,2 \%$.

\section{Respons Utama}

Pengamatan utama adalah pengamatan yang datanya digunakan untuk menjawab hipotesis, yang meliputi : vigor benih, panjang akar kecambah, panjang pupus kecambah, dan bobot kering kecambah.

\section{a. Vigor Benih}

Hasil perhitungan analisis sidik ragam mengenai vigor benih, tidak terjadi pengaruh interaksi antara konsentrasi giberelin dengan varietas padi sawah pada cekaman salinitas tinggi. Begitu juga dengan perlakuan secara mandiri, baik perlakuan konsentrasi giberelin maupun varietas padi sawah tidak menunjukkan pengaruh yang nyata terhadap vigor benih. Hal ini disebabkan setiap tingkatan konsentrasi giberelin belum terlihat efeknya pada umur perkecambahan 7 HST, sedangkan varietas padi sawah yang diujicobakan diduga memiliki karakteristik kemampuan perkecambahan yang sama, terutama pada kondisi lingkungan yang tercekam salinitas. Untuk lebih jelasnya pengaruh konsentrasi giberelin dan varietas padi sawah terhadap vigor benih pada cekaman salinitas tinggi dapat dilihat pada Tabel 2.

Tabel 2. Pengaruh Konsentrasi Giberelin dan Varietas Padi Sawah terhadap Vigor Benih pada Cekaman Salinitas Tinggi

\begin{tabular}{|c|c|c|}
\hline No. & Perlakuan & Vigor Benih (\%) \\
\hline \multirow{5}{*}{1.} & $\begin{array}{l}\text { Pengaruh Konsentrasi Giberelin : } \\
\mathrm{g}_{0}\left(0 \mathrm{mg} \cdot \mathrm{L}^{-1}\right)\end{array}$ & $66,25 \mathrm{a}$ \\
\hline & $\mathrm{g}_{1}\left(20 \mathrm{mg} \cdot \mathrm{L}^{-1}\right)$ & $65,75 \mathrm{a}$ \\
\hline & $\mathrm{g}_{2}\left(40 \mathrm{mg} \cdot \mathrm{L}^{-1}\right)$ & $67,56 \mathrm{a}$ \\
\hline & $\mathrm{g}_{3}\left(60 \mathrm{mg} \cdot \mathrm{L}^{-1}\right)$ & $60,63 \mathrm{a}$ \\
\hline & Pengaruh Varietas Padi Sawah : & \\
\hline \multirow{8}{*}{2.} & $\mathrm{p}_{1}$ (Inpari 10 Laeya) & $62,00 \mathrm{a}$ \\
\hline & $\mathrm{p}_{2}($ Inpari 20$)$ & $63,38 \mathrm{a}$ \\
\hline & $\mathrm{p}_{3}$ (Inpari 25 Opak Jaya) & $76,63 \mathrm{a}$ \\
\hline & $\mathrm{p}_{4}($ Inpari 26) & $59,25 \mathrm{a}$ \\
\hline & $\mathrm{p}_{5}($ Inpari 27) & $58,25 \mathrm{a}$ \\
\hline & p6 (Inpari 30 Ciherang sub.1) & $68,38 \mathrm{a}$ \\
\hline & $\mathrm{p}_{7}$ (Inpara 4) & $60,38 \mathrm{a}$ \\
\hline & $\mathrm{p}_{8}$ (Banyuasin) & $72,13 \mathrm{a}$ \\
\hline
\end{tabular}




\section{b. Panjang Akar Kecambah}

Hasil perhitungan analisis sidik ragam panjang akar kecambah, tidak terjadi pengaruh interaksi antara konsentrasi giberelin dengan varietas padi sawah. Begitu juga dengan perlakuan secara mandiri, baik perlakuan konsentrasi giberelin maupun varietas padi sawah tidak menunjukkan pengaruh yang nyata terhadap panjang akar kecambah. Hal ini disebabkan panjang akar kecambah akan lebih terlihat dengan jelas pada umur perkecambahan diatas 7 HST, sehingga konsentrasi giberelin maupun perlakuan varietas padi sawah belum terlihat dengan jelas pengaruhnya. Pengaruh konsentrasi giberelin dan varietas padi sawah terhadap panjang akar kecambah pada cekaman salinitas tinggi dapat dilihat pada Tabel 3.

Tabel 3. Pengaruh Konsentrasi Giberelin dan Varietas Padi Sawah terhadap Panjang Akar Kecambah pada Cekaman Salinitas Tinggi

\begin{tabular}{|c|c|c|}
\hline No. & $\begin{array}{l}\text { Perlakuan } \\
\end{array}$ & Panjang Akar Kecambah (cm) \\
\hline \multirow{5}{*}{1.} & Pengaruh Konsentrasi Giberelin : & \\
\hline & $\mathrm{g}_{0}\left(0 \mathrm{mg} \cdot \mathrm{L}^{-1}\right)$ & $5,70 \mathrm{a}$ \\
\hline & $\mathrm{g}_{1}\left(20 \mathrm{mg} \cdot \mathrm{L}^{-1}\right)$ & $5,06 \mathrm{a}$ \\
\hline & $\mathrm{g}_{2}\left(40 \mathrm{mg} \cdot \mathrm{L}^{-1}\right)$ & $5,47 \mathrm{a}$ \\
\hline & $\mathrm{g}_{3}\left(60 \mathrm{mg} \cdot \mathrm{L}^{-1}\right)$ & $4,75 \mathrm{a}$ \\
\hline \multirow{9}{*}{2.} & Pengaruh Varietas Padi Sawah : & \\
\hline & $\mathrm{p}_{1}$ (Inpari 10 Laeya) & $4,80 \mathrm{a}$ \\
\hline & $\mathrm{p}_{2}($ Inpari 20) & $5,22 \mathrm{a}$ \\
\hline & $\mathrm{p}_{3}$ (Inpari 25 Opak Jaya) & $4,80 \mathrm{a}$ \\
\hline & $\mathrm{p}_{4}($ Inpari 26) & $5,91 \mathrm{a}$ \\
\hline & $\mathrm{p}_{5}($ Inpari 27) & $4,51 \mathrm{a}$ \\
\hline & $\mathrm{p}_{6}$ (Inpari 30 Ciherang sub.1) & $5,33 \mathrm{a}$ \\
\hline & $\mathrm{p}_{7}($ Inpara 4$)$ & $6,11 \mathrm{a}$ \\
\hline & $\mathrm{p}_{8}$ (Banyuasin) & $5,29 \mathrm{a}$ \\
\hline
\end{tabular}
Jarak Berganda Duncan pada taraf nyata $5 \%$.

\section{c. Panjang Pupus Kecambah}

Hasil perhitungan analisis sidik ragam, tidak terjadi pengaruh interaksi antara konsentrasi giberelin dengan varietas padi sawah terhadap panjang pupus kecambah pada cekaman salinitas tinggi. Untuk lebih jelasnya pengaruh konsentrasi giberelin dan varietas padi sawah terhadap panjang pupus kecambah pada cekaman salinitas tinggi dapat dilihat pada Tabel 4.

Tabel 4 menunjukkan bahwa secara mandiri konsentrasi giberelin berpengaruh nyata terhadap panjang pupus kecambah. Perlakuan g0 (0 mg.L $\left.\mathrm{L}^{-1}\right)$ berbeda nyata dengan perlakuan lainnya, tetapi tidak berbeda nyata dengan perlakuan g1 (20 mg. $\left.\mathrm{L}^{-1}\right)$. Hal ini disebabkan perkecambahan dapat dipengaruhi baik secara langsung maupun tidak langsung oleh zat pengatur tumbuh giberelin yang terdapat pada tanaman usia perkecambahan, sehingga pemberian giberelin dengan jumlah tertentu membantu dalam pemanjangan pupus kecambah tetapi ada juga yang tidak mempengaruhinya. Menurut Arteca (1996), giberelin disintesis melalui jalur asam mevalonat di dalam akar muda dan biji yang sedang berkembang. 
Tabel 4. Pengaruh Konsentrasi Giberelin dan Varietas Padi Sawah terhadap Panjang Pupus Kecambah pada Cekaman Salinitas Tinggi

\begin{tabular}{|c|c|c|}
\hline No. & Perlakuan & Panjang Pupus Kecambah (cm) \\
\hline \multirow{5}{*}{1.} & Pengaruh Konsentrasi Giberelin : & \\
\hline & $\mathrm{g}_{0}\left(0 \mathrm{mg} \cdot \mathrm{L}^{-1}\right)$ & 2,60 a \\
\hline & $\mathrm{g}_{1}\left(20 \mathrm{mg} \cdot \mathrm{L}^{-1}\right)$ & $2,97 \mathrm{ab}$ \\
\hline & $\mathrm{g}_{2}\left(40 \mathrm{mg} \cdot \mathrm{L}^{-1}\right)$ & $3,43 \mathrm{bc}$ \\
\hline & $\mathrm{g}_{3}\left(60 \mathrm{mg} . \mathrm{L}^{-1}\right)$ & $3,52 \mathrm{c}$ \\
\hline \multirow{9}{*}{2.} & Pengaruh Varietas Padi Sawah : & \\
\hline & $\mathrm{p}_{1}$ (Inpari 10 Laeya) & 3,19 a \\
\hline & $\mathrm{p}_{2}($ Inpari 20$)$ & 3,09 a \\
\hline & p3 (Inpari 25 Opak Jaya) & 2,98 a \\
\hline & $\mathrm{p}_{4}($ Inpari 26) & 3,94 a \\
\hline & $\mathrm{p}_{5}($ Inpari 27) & 2,87 a \\
\hline & p6 (Inpari 30 Ciherang sub.1) & $3,18 \mathrm{ab}$ \\
\hline & $\mathrm{p}_{7}$ (Inpara 4) & $2,82 \mathrm{ab}$ \\
\hline & $\mathrm{p}_{8}$ (Banyuasin) & $2,97 \mathrm{~b}$ \\
\hline
\end{tabular}

Secara mandiri antar varietas yang diuji menunjukkan perbedaan yang tidak nyata dalam panjang pupus kecambah. Hal ini $\mathrm{k}$ antar varietas padi yang diuji umur perkecambahannya tergolong muda dan secara genetik pada umur perkecambahan panjang pupus akar untuk semua varietas yang diuji tidak berbeda nyata.

\section{d. Bobot Kering Kecambah}

Hasil perhitungan analisis sidik ragam mengenai bobot kering kecambah, terjadi pengaruh interaksi antara konsentrasi giberelin dengan varietas padi sawah pada cekaman salinitas tinggi. Untuk lebih jelasnya pengaruh konsentrasi giberelin dan varietas padi sawah terhadap bobot kering kecambah pada cekaman salinitas tinggi dapat dilihat pada Tabel 5.

Pada varietas Inpari 10 Laeya (p1), menunjukkan bahwa pemberian giberelin pada berbagai konsentrasi memberikan pengaruh yang nyata terhadap bobot kering kecambah. Begitu juga dengan varietas Inpari 20 (p2), menunjukkan bahwa semua konsentrasi giberelin berpengaruh nyata terhadap bobot kering kecambah. Pada varietas Inpari 25 Opak Jaya (p3) juga menunjukkan hal yang sama, bahwa pada semua konsentrasi giberelin berpengaruh nyata terhadap bobot kering kecambah. Pengaruh terhadap bobot kering kecambah oleh konsentrasi giberelin pada varietas padi Inpari 26 (p4), menunjukkan pengaruh berbeda nyata pada semua tingkatan konsentrasi giberelin. Pada varietas Inpari 27 (p5) di setiap tingkatan konsentrasi giberelin berpengaruh nyata terhadap bobot kering kecambah. Sedangkan pada varietas Inpari 30 Ciherang Sub. 1 (p6) menunjukkan bahwa pemberian konsentrasi giberelin dengan konsentrasi 0 mg.L $\mathrm{L}^{-1}, 20$ mg. $\mathrm{L}^{-1}$ dan $40 \mathrm{mg} . \mathrm{L}^{-1}$ memberikan pengaruh berbeda nyata terhadap bobot kering kecambah, kecuali pada konsentrasi 60 mg. $\mathrm{L}^{-1}$ memberikan pengaruh tidak berbeda nyata terhadap bobot kering kecambah. Varietas padi Inpara 4 (p7), memberikan gambaran bahwa pemberian konsentrasi giberelin sebesar $0 \mathrm{mg} . \mathrm{L}^{-1}$ atau 
tanpa giberelin justru memberikan pengaruh yang berbeda nyata terhadap bobot kering kecambah. Pada varietas Banyuasin (p8), pemberian giberelin pada setiap tingkatan konsentrasi memberikan pengaruh yang nyata terhadap bobot kering kecambah.

Tabel 5. Pengaruh Konsentrasi Giberelin dan Varietas Padi Sawah terhadap Bobot Kering Kecambah pada Cekaman Salinitas Tinggi

\begin{tabular}{llcll}
\hline \multirow{2}{*}{ Varietas } & \multicolumn{4}{c}{ Konsentrasi giberelin (mg.L ${ }^{-1}$ ) } \\
\cline { 2 - 5 } & $\mathrm{g}_{0}(0)$ & $\mathrm{g}_{1}(20)$ & $\mathrm{g}_{2}(40)$ & $\mathrm{g}_{3}(60)$ \\
\hline $\mathrm{p}_{1}$ (Inpari 10 Laeya) & $0,015 \mathrm{c}$ & $0,0150 \mathrm{c}$ & $0,0145 \mathrm{c}$ & $0,0158 \mathrm{~b}$ \\
$\mathrm{p}_{2}$ (Inpari 20) & $0,015 \mathrm{ab}$ & $0,0128 \mathrm{bc}$ & $0,0135 \mathrm{bc}$ & $0,0133 \mathrm{ab}$ \\
$\mathrm{p}_{3}$ (Inpari 25 Opak Jaya) & $0,013 \mathrm{bc}$ & $0,0123 \mathrm{~b}$ & $0,0118 \mathrm{ab}$ & $0,0125 \mathrm{a}$ \\
$\mathrm{p}_{4}$ (Inpari 26) & $0,014 \mathrm{c}$ & $0,0138 \mathrm{bc}$ & $0,0130 \mathrm{~b}$ & $0,0140 \mathrm{ab}$ \\
$\mathrm{p}_{5}$ (Inpari 27) & $0,014 \mathrm{c}$ & $0,0150 \mathrm{c}$ & $0,0128 \mathrm{~b}$ & $0,0135 \mathrm{ab}$ \\
$\mathrm{p}_{6}$ (Inpari 30 Ciherang sub.1) & $0,013 \mathrm{bc}$ & $0,0123 \mathrm{~b}$ & $0,0123 \mathrm{~b}$ & $0,0128 \mathrm{a}$ \\
$\mathrm{p}_{7}$ (Inpara 4) & $0,010 \mathrm{c}$ & $0,0083 \mathrm{a}$ & $0,0100 \mathrm{a}$ & $0,0098 \mathrm{a}$ \\
$\mathrm{p}_{8}$ (Banyuasin) & $0,014 \mathrm{c}$ & $0,0143 \mathrm{bc}$ & $0,0148 \mathrm{c}$ & $0,0148 \mathrm{~b}$ \\
\hline
\end{tabular}

Keterangan :Angka rata-rata yang diikuti huruf yang sama menunjukkan berbeda tidak nyata berdasarkan Uji Jarak Berganda Duncan pada taraf nyata $5 \%$.

Pertumbuhan juga dapat diukur dari pertambahan biomassa yang dihasilkan tanaman. Pendekatan yang digunakan untuk pengukuran biomassa tanaman adalah menimbang berat basah dan berat kering tanaman. Berat kering lebih disukai untuk menaksir pertumbuhan tanaman, karena mencerminkan akumulasi senyawa organik yang disintesis tanaman dari senyawa anorganik. Unsur hara yang diserap tanaman dari lingkungan juga memberi kontribusi pada berat kering tanaman (Sitompul dan Guritno, 1995). Penggunaan dalam takaran sangat sedikit dapat mendorong, menghambat, mengubah pertumbuhan tanaman, dan pergerakan (taksis) pada tumbuhan.

\section{SIMPULAN}

Berdasarkan hasil penelitian dan pembahasan yang telah diuraikan dimuka, maka dapat ditarik kesimpulan sebagai berikut :

1. Terdapat pengaruh interaksi antara konsentrasi giberelin dan beberapa varietas padi sawah pada cekaman salinitas tinggi terhadap perkecambahan padi sawah.

a) Terdapat pengaruh interaksi antara konsentrasi giberelin dan beberapa varietas padi sawah pada cekaman salinitas tinggi terhadap bobot kering kecambah.

b) Konsentrasi giberelin secara mandiri berpengaruh terhadap panjang pupus kecambah.

2. Terdapat konsentrasi giberelin $\left(\mathrm{GA}_{3}\right)$ dan varietas padi sawah yang menghasilkan perkecambahan, pertumbuhan dan hasil terbaik pada cekaman salinitas tinggi.

\section{DAFTAR PUSTAKA}

Afzal, I., Basra, S.M.A \& Iqbal, A. (2005). The Effect of Seed Soaking With Plant Growth Regulators on Seedling Vigor of Wheat Under Salinity Stress. Journal of Stress Physiology and Biochemistry, 1(1), 6 - 14.

Aksi Agraris Kanisius. (1990). Budidaya Tanaman Padi. Kanisius, Yogyakarta.

Aksi Agraris Kanisius. (1992). Budidaya Tanaman Padi. Kanisius, Yogyakarta.

Arteca, R.N. (1996). Plant Growth Substances: Principles and Applications. Chapman and Hall, New York. 
Ashraf, M. \& Foolad, M.R. (2005). Pre-sowing Seed Treatment - a Shotgun Approach to Improve Germination, Growth and Crop Yield Under Saline and Non-saline Conditions. Adv. Agron. 88, 223-271.

Audus, L.J. (1972). Plant Growt Substances. Leonard Hill Books. London.

Badan Penelitian dan Pengembangan Pertanian. (2007). Pengelolaan Tanaman Terpadu Padi Lahan Rawa Pasang Surut. Badan Penelitian dan Pengembangan Pertanian, Jakarta.

Badan Penelitian dan Pengembangan Pertanian. (2010). Deskripsi Varietas Unggul Baru. Padi. Balibangtan Kementerian Pertanian, Sukamandi.

Badan Penelitian dan Pengembangan Pertanian. (2013). Deskripsi Varietas Unggul Baru. Padi. Balibangtan Kementerian Pertanian, Sukamandi.

Castro, R.V., \& Sabado, S.R. (1977). Influence of Varying Level of Salt Applied at Different Stages on The Growth and Yield of Rice. Grains J., 2(3), 43 - 45.

Copeland, L.0. (1978). Seed Germination. Principles of Seed Science and Technology 4: 7. Burgess Publishing Company, Minneapolis - Minnesota.

Sasmitamihardja, D \& Arbayah,S. (1996). Fisiologi Tumbuhan. Jurusan Biologi FMIPA IPB, Bogor.

Priyansyah, D.R. (2012). Keragaan dan Identifikasi Genotip Padi Sawah Toleran Terhadap Cekaman Salinitas Tinggi. Skripsi. Fakultas Pertanian Universitas Winaya Mukti, Tanjungsari.

Devian. (2012). Karakteristik dan Deskripsi Tanaman Padi. URL: http://pagemenu.blogspot. com/2012/09/karakteristik-dandeskripsi-tanaman-padi.html (diakses tanggal 13 Agustus 2014).

Dharmawan, A. (2005). Ekologi Hewan. Malang: Universitas Muhammadiyah Press.

Campbell. (2003). Biologi Jilid 2. Erlangga, Jakarta.

Direktorat Jendral Prasarana dan Sarana Pertanian. (2013). Kajian Potensi Lahan Untuk Perluasan Tanaman Padi Sawah. Dirjen Prasarana dan Sarana Pertanian, Kementerian Pertanian Republik Indonesia.

Doorenbos, J. \& Pruitt, W.O. (1977). Guidlines for Predicting Crop Water Requirements. FAO Irrigation and Drainage Paper. Food and Agriculture
Organization of The United Nations. Rome. 61.

Dunand, R. T. (1999). Improvement of Rice Production With Plant Growt Regulators. Rice Research Centre. Lousiana State University.

Dunand, R. T. \& Dilly, R.R. (1997). New Use for Gibberelic Acid Seed Treatment in Rice. Louisiana Agriculture 40 (2) : 20.

Dwijoseputro. (1984). Pengantar Fisiologi Tumbuhan. Granesia, Jakarta.

Esrita. (2010). Dalam Erlin Yuli A., Tutik Nurhidayati dan Kristanti Indah P. 2011. Aplikasi Zat Pengatur Tumbuh Indole Acetic Acid (IAA) dan Kinetin pada Cekaman Salinitas ( $\mathrm{NaCl})$ Terhadap Pertumbuhan Eksplan Nodus Kultur Jaringan Tembakau (Nicotiana tabacum L. var. Prancak 95). Tugas Akhir. Jurusan Biologi, Fakultas Matematika dan Ilmu Pengetahuan Alam Institut Teknologi Sepuluh Nopember, Surabaya.

Food and Agriculture Organization. (2005). 20 Hal untuk Diketahui Tentang Dampak Air Laut pada Lahan di Provinsi NAD. URL: http://www.fao.org (diakses tanggal 13 Agustus 2014).

Hess, D. (1975). Plant Physiology. Springer Verlag New York Inc. United State of America. 333p. Dalam Wattimena, G.A. 1988. Zat Pengatur Tumbuh Tanaman. Pusat Antar Universitas IPB, Bogor. 247 hal.

Wiroatmodjo, J. (1986). Biofiltrasi pada Budidaya Padi di Daerah yang Terkena Intrusi Air Laut. Buletin Agronomi 19 (1).

Kaddah, M. T. (1963). Salinity Effect on Growth of Rice at The Seedling and Inflorescence Stages of Development. Soil Sci. 96 : 105 - 111. Dalam Ketut Kartha Dinata. 1985. Pengaruh Salinitas Terhadap Pertumbuhan dan Produksi Varietas Atomita II dan IR 32. Tesis. Fakultas Pasca Sarjana Institut Pertanian Bogor, Bogor.

Kurniasih, B. (2002). Pengaruh Salinitas Terhadap Perkecambahan. Agr. UMY, 10(1), $14-23$.

Sutopo, L. (2004). Teknologi Benih. PT Raja Grafindo Persada, Jakarta.

Utama, M.Z.H, Haryoko, W, Munir, R \& Sunadi. (2009). Penapisan Varietas Padi Toleran Salinitas pada Lahan Rawa di Kabupaten Pesisir Selatan. Jurnal Agronomi Indonesia, 37(2), 101 - 106. 
Manurung, S.O. \& Ismunadji, M. (1988). Morfologi dan Fisiologi Padi. Pusat Penelitian dan Pengembangan Tanaman Pangan, Bogor.

Manurung, S.O. \& Ismunadji, M. (1989). Morfologi Padi, Dalam Padi Buku I, Pusat Penelitian dan Pengembangan Tanaman, Bogor. Hal, 319.

Marschner, H. (1995). Mineral Nutrition of Higher Plants. Dalam Ratna Yuniati. 2004. Penapisan Galur Kedelai Glycine max L. Toleran Terhadap $\mathrm{NaCl}$ untuk Penanaman di Lahan Salin. Makara Sains, 8(1), 21 - 24.

Marwanto S., Rachman A., Erfandi D. \& Subiksa, I.G.M. (2009). Tingkat Salinitas Tanah pada Lahan Sawah Intensif di Kabupaten Indramayu, Jawa Barat. Balai Penelitian Tanah, Bogor.

McGuire, P. \& Dvorah, J. (1981). High Salt Tolerance Potensial in Wheatgrasses. Crop Sci. 21 : 702 - 705. Dalam Ketut Kartha Dinata. 1985. Pengaruh Salinitas Terhadap Pertumbuhan dan Produksi Padi Varietas Atomita II dan IR 32. Fakultas Pascasarjana Institut Pertanian Bogor, Bogor.

Moore, T.C. (1979). Biochemistry and Physiology of Plant Hormones. Springer - Verlag New York Inc., New York.

Moorman, F.R. \& Breemen, V.N. (1978). Rice : Soil, Water Land. International Rice Research Institute, Los Baños, Laguna, Philippines.

Murakami, Y. (1995). Gibberellins. 182 - 189. Dalam Supriyadi. 2006. Pengaruh Konsentrasi dan Waktu Aplikasi Giberelin Gibgro 10 SP Terhadap Pertumbuhan, Hasil dan Mutu Fisik Hasil Padi Sawah (Oryza sativa L.). Skripsi. Program Studi Agronomi Fakultas Pertanian Institut Pertanian Bogor, Bogor.

Notohadiprawiro. (1998). Tanah dan Lingkungan. Direktorat Jendral Pendidikan Tinggi Departemen Pendidikan dan Kebudayaan, Jakarta. Hal 236.

Orcutt, D. M. \& Nielsen, E.T. (2000). The Physiology of Plant Under Stress : Soil and Biotic Factors. Dalam Ai Komariah, H. 2011. Tanaman pada Lingkungan Tercekam Edisi 2. Winaya Mukti University Press, Bandung.
Osmand. (1987). Ecology 2nd Edition: Individual, Populations and Communities. Boston Oxford, London.

Pearson \& Ayres. (1960). Dalam Sriwidodo. 1985. Penyaringan Sifat Toleran Terhadap Salinitas pada Padi Sawah dan Kaitannya dengan Beberapa Karakter Agronomik. Tesis. Fakultas Pascasarjana Institut Pertanian Bogor, Bogor.

Poerwowidodo. (2002). Metode Selidik Tanah. Usaha Nasional, Surabaya.

Rismunandar. (1988). Hormon Tumbuhan dan Ternak. Penebar Swadaya, Jakarta.

Sadjad, S. (1993). Dari Benih kepada Benih. Grasindo, Jakarta.

Salisbury, F.B. (1957). Plant Life. Scientific American Inc., New York.

Salisbury, F.B. \& Ross, C.W. (1995). Fisiologi Tumbuhan Jilid 3. (Terjemahan: Dian R. Lukman dan Sumaryono). Ganesha, Bandung.

Sinaga. (2008). Peran Air Bagi Tanaman. URL: http:// puslit.mercubuana.ac.id/ file/8artikel\%20sinaga.pdf. (diakses pada 09 Juli 2009).

Sitompul, S.M. \& Guritno, B. (1995). Analisis Pertumbuhan Tanaman. UGM-Press. Yogyakarta.

Soemartono, B.S \& Hardjono, R. (1980). Bercocok Tanam Padi. C. V. Yasaguna, Jakarta.

Soemartono, B.S \& Hardjono, R. (1982). Bercocok Tanam Padi. C. V. Yasaguna, Jakarta.

Sposito, G. (2008). The Chemistry of Soils. Oxford University Press. New York USA. 329 p. Dalam Ahmad Muharram Ibnu Rusd. 2011. Pengujian Toleransi Padi (Oryza sativa L.) Terhadap Salinitas pada Fase Perkecambahan. Skripsi. Departemen Agronomi dan Hortikultura Fakultas Pertanian Institut Pertanian Bogor, Bogor.

Stark, J. C. \& Jarrell, W.M. (1980). SalinityInduce Modification in The Respons of Maize to Water Deficits. Agron. J. 71 : 425 - 427. Dalam Ketut Kartha Dinata. 1985. Pengaruh Salinitas Terhadap Pertumbuhan dan Produksi Padi Varietas Atomita II dan IR 32. Fakultas Pascasarjana Institut Pertanian Bogor, Bogor.

Sucipto. (2009). Morfologi Tanaman Padi. http://perbenihan.blogspot. com/2009/02/morfologi-tanaman- 
padi.html. (diakses tanggal 9 Agustus 2014).

Sulaiman, S. (1980). Penyaringan Varietas Padi Sawah bagi Penyesuaian Terhadap Tanah Berkadar Garam Tinggi. Tesis. Pasca Sarjana. Institut Pertanian Bogor, Bogor.

Sumarsono, A.S., Budianto, S. \& Widjayanto, D.W. (2006). Penampilan Morfologi dan Produksi Bahan Kering Hijauan Rumput Gajah dan Kolonjono di Lahan Pantai yang Dipupuk dengan Pupuk Organik dan Dua Level Pupuk Urea. Fakultas Peternakan Universitas Dipenogoro, Semarang.

Suparyono, B. \& Setyono, A. (1993). Padi. PT. Penebar Swadaya, Jakarta.

Suparyono, B. \& Setyono, A. (1997). Padi. PT. Penebar Swadaya, Jakarta.

Supriyadi. (2006). Pengaruh Konsentrasi dan Waktu Aplikasi Giberelin Gibgro 10 SP Terhadap Pertumbuhan, Hasil dan Mutu Fisik Hasil Padi Sawah (Oryza sativa L.). Skripsi. Program Studi Agronomi Fakultas Pertanian Institut Pertanian Bogor, Bogor.

Sutedjo, M \& Kartaspoetra, A.G. (1989). Fisiologi Tanaman 1. Bumi Aksara, Jakarta.

Suwarno \& Solahudin, S. (1983). Toleransi Varietas Padi Terhadap Salinitas pada Fase Perkecambahan. Bul. Agron, XIV (3), 1-11.

Suwarno. (1985). Pewarisan dan Fisiologi Sifat Toleran Terhadap Salinitas pada Tanaman Padi. Disertasi. Program Pasca Sarjana, Institut Pertanian Bogor, Bogor. 87 hal.

Tan, K.H. (2000). Environmental Soil Science $2^{\text {nd }}$ ed. Marcel Dekker. New York. 452 p.

Wahyuningtyas, R. (1994). Pembentukan dan Perkembangan Buah Tanaman Pare Pahit (Momordica charantia Linn.) dengan Perlakuan Auksin dan Giberelin. Skripsi. Fakultas Biologi Universitas Gadjah Mada, Yogyakarta.

Warsa, T \& Cucu, S. A. (1982). Teknik Perancangan Percobaan (Rancangan dan Analisis). Serial Pengenalan Dasar - dasar Statistik Terapan. Fakultas Pertanian Universitas Padjadjaran, Bandung.

Wattimena, G. A. (1988). Zat Pengatur Tumbuh Tanaman. Pusat Antar Universitas IPB, Bogor. 247 hal.
Yamashita, K. \& Matsumoto, H. (1997). Plant Nutritions. 20-233.Yan, W., R. Dilday, R. Helms and F. Bourland. 2004. Effect of Giberrellic Acid on Rice Germination and Seedling Emergence in Stress Condition. Arkansas Agricultural Experiment Station Research Series 517. $303-316$.

Yuniati, R. (2004). Penapisan Galur Kedelai Glycine max L. Toleran Terhadap $\mathrm{NaCl}$ untuk Penanaman di Lahan Salin. Makara Sains, 8(1), 21 - 24. 